\title{
Prediction of the Energy Self-Sufficiency Rate of Major New Renewable Energy Types Based on Zero-Energy Building Certification Cases in South Korea
}

\author{
Seongjo Wang ${ }^{1}$, Sungho Tae ${ }^{2, *}$ and Hyeongjae Jang ${ }^{3, *}$ \\ 1 Department of Smart City Engineering, Hanyang University, 55 Hanyangdaehak-ro, Sangrok-gu, \\ Ansan 15588, Korea; eco_wang@naver.com \\ 2 School of Architecture and Architectural Engineering, Hanyang University, 55 Hanyangdaehak-ro, \\ Sangrok-gu, Ansan 15588, Korea \\ 3 Department of Architectural Engineering, Hanyang University, 55 Hanyangdaehak-ro, Sangrok-gu, \\ Ansan 15588, Korea \\ * Correspondence: jnb55@hanyang.ac.kr (S.T.); duethj@gmail.com (H.J.); Tel.: +82-31-400-5187 (S.T.); \\ +82-31-436-8077 (H.J.)
}

Citation: Wang, S.; Tae, S.; Jang, H. Prediction of the Energy Self-Sufficiency Rate of Major New Renewable Energy Types Based on Zero-Energy Building Certification Cases in South Korea. Sustainability 2021, 13, 11552. https://doi.org/ $10.3390 /$ su132011552

Academic Editors: Anna Visvizi, Wadee Alhalabi, Shahira Assem Abdel Razek, Paolo Gerli and Orlando Troisi

Received: 23 August 2021 Accepted: 15 October 2021 Published: 19 October 2021

Publisher's Note: MDPI stays neutral with regard to jurisdictional claims in published maps and institutional affiliations.

Copyright: (c) 2021 by the authors. Licensee MDPI, Basel, Switzerland. This article is an open access article distributed under the terms and conditions of the Creative Commons Attribution (CC BY) license (https:/ / creativecommons.org/licenses/by/ $4.0 /)$.

\begin{abstract}
There is an increasing interest in new renewable energy sources for achieving net zero emissions. Consequently, the construction industry has mandated zero-energy building certification (ZEB), through the usage of new renewable energy. However, because of the variations in the energy selfsufficiency rate (ESR) among the new renewable energy types, incorrect ESR prediction at the design stage may lead to problems. Hence, in this study, the ESR and construction cost are analyzed for each new renewable energy capacity to predict the ESR of photovoltaic (PV), building integrated photovoltaic (BIPV), geothermal, and fuel cell systems. Passive and active technology elements of the ZEB cases in Korea are analyzed, and by establishing a standard model with the average value of each case, the ESR is calculated for each new renewable energy capacity, and the calculation formulas are derived. The results indicate that for the PV and BIPV systems, the rate of ESR increases with the capacity $(\mathrm{kWp})$ and is constant at $0.54 \%$ and $0.34 \%$, respectively. However, for the geothermal system and fuel cells, the average ESR is $0.016 \%$ and $1.46 \%$, respectively, but as the rate of ESR increase with the capacity $(\mathrm{kW})$ gradually decreases, the calculation formulas are derived with a log graph.
\end{abstract}

Keywords: zero energy building; ZEB; energy self-sufficiency rate; new renewable energy

\section{Introduction}

According to "The Special Report on Global Warming of $1.5^{\circ} \mathrm{C}^{\prime}$ by the Intergovernmental Panel on Climate Change (IPCC) in October 2018, in order to maintain the increase in the global average temperature within $1.5^{\circ} \mathrm{C}$, carbon dioxide emissions need be reduced by 2030 by at least $45 \%$ compared to 2010 , and "net zero", which indicates a net-zero carbon emission state, should be achieved across the globe by 2050 [1,2]. Six countries in Europe, including Sweden (2017), the United Kingdom (2019), Denmark (2019), France (2020), and Hungary (2020), have already passed net zero legislation, the European Union (EU) has committed to the establishment of Europe as the first climate-neutral continent by 2050 (2019) [3,4]. In Asia, China (2020) and Japan (2020) have pledged net zero. In addition, the United States has rejoined the Paris Agreement (2021) and committed to achieving net zero by 2050 [5,6]. Since the enforcement of the Paris Agreement in 2016, 121 countries have joined the Climate Ambition Alliance with the objective of achieving net zero by 2050, demonstrating a shared global commitment toward achieving zero greenhouse gas emissions $[7,8]$.

In 2020, South Korea introduced the 'Korean New Deal', which is an overarching national project to derive innovative growth in the post-COVID-19 era. The country announced the promotion of a strategic policy with three major projects, including the 
Digital New Deal, digital and green convergence, and Green New Deal, and ten priority tasks. Among these major national projects, green energy is included as a priority task in the Green New Deal. The essence of the Korean New Deal is its energy policy and implementation, which is promoted with the objective of achieving a net-zero society through global climate change response, energy security, and the development and support of ecofriendly industries $[9,10]$.

The strategy for promoting net zero emissions in the building sector includes main tasks such as expanding new renewable energy like solar and geothermal energies and achieving zero energy in public buildings [11]. Accordingly, South Korea has mandated that starting in 2020, newly built public buildings with a minimum floor area of $1000 \mathrm{~m}^{2}$ must obtain zero energy building certification (ZEB). To do this, the energy self-sufficiency rate (ESR), ratio of energy production to energy consumption, of a certain level or higher must be achieved [12,13].

Increasing the ESR requires energy production (i.e., the installation of new renewable energy systems); however, because the ESR efficiencies of the new renewable energies are significantly different and construction cost is involved depending on the type, the implementation of an optimal design of new renewable energy with careful analysis from the design stage is necessary [14]. However, for ESR analysis, multiple aspects, such as passive and active technology elements including construction, machinery, electricity, and new renewable energy, as well as the size and utility of the building need to be considered, rendering ESR prediction difficult $[15,16]$. Moreover, as ZEB has been implemented only recently, data on similar cases are limited, leading to problems such as design changes due to noncompliance with the ESR condition, which increases the construction cost and prolongs the construction period $[17,18]$.

In view of the above, this study investigates the ZEB cases in Korea in order to predict the ESR of the major new renewable energy types and analyzes the ESR and construction costs of these energy types by selecting a standard model. Furthermore, the ESR formula for each major new renewable energy type is derived to allow the construction stakeholders (building owner, architect, and builder) to assess the optimal share of new renewable energy at the design stage, which is neither excessive nor insufficient. The flowchart of this study is presented in Figure 1.

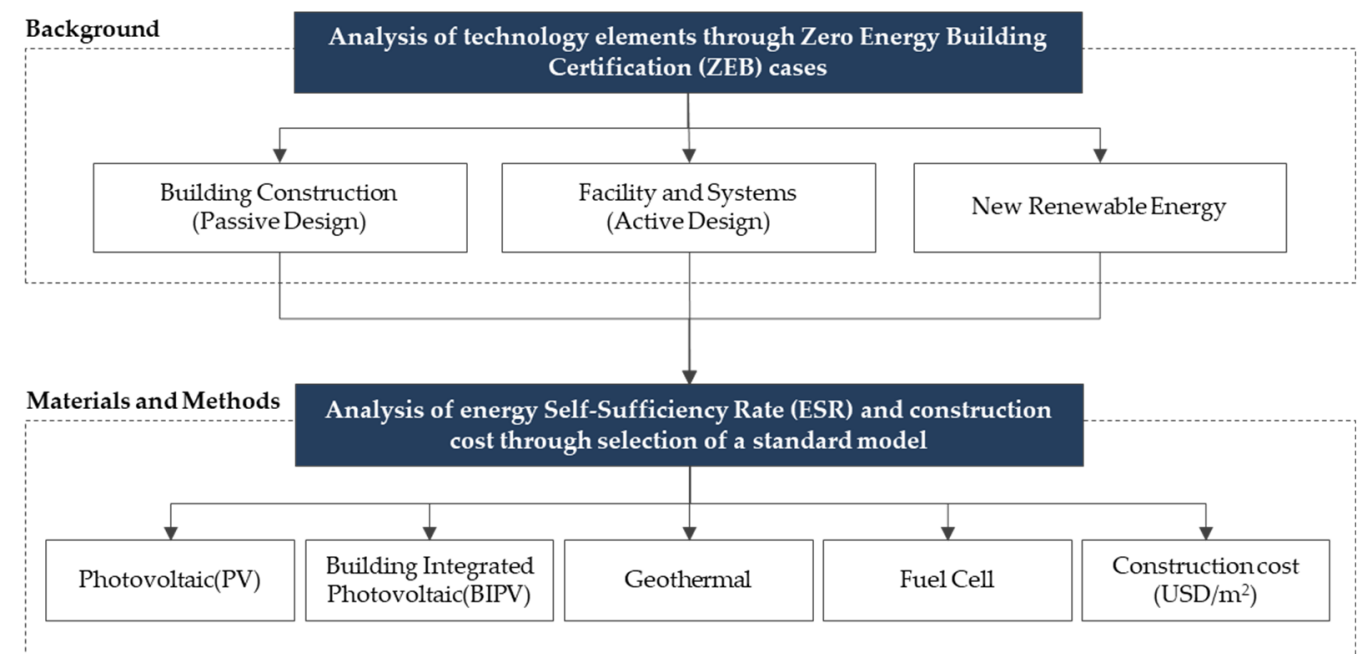

Figure 1. Flow chart of this study.

\section{Background}

\subsection{Zero-Energy Buildings}

A zero-energy building aims to achieve net zero energy consumption by balancing the energy consumption of the building and energy production onsite using new renewable energy. In the United States, it refers to an energy neutral building that supplies as 
much energy as it consumes from the renewable energy grid (i.e., a building in which the annual energy consumption and energy generation are the same) $[13,19]$. In the European Union (EU), a zero-energy building refers to a building with considerably high energy performance in terms of the construction and facilities for heating, cooling, hot water heating, lighting, and ventilation, and includes new renewable energy produced from the land on which the building is situated or the adjacent areas [13,20]. In Japan, it refers to a building with zero net annual energy consumption and $\mathrm{CO}_{2}$ emissions by improving the energy saving performance of the building and facilities as well as the utilization of new renewable energy onsite $[13,21]$.

Hence, a zero-energy building can be regarded as a building that achieves energy independence by balancing its energy consumption and production. Such buildings aim to minimize energy consumption through passive technology elements related to the construction and active technology elements associated with systems and electricity, and maximize energy production through new renewable energy, increasing the ESR [22]. The concept of a zero-energy building is illustrated in Figure $2[12,22]$.
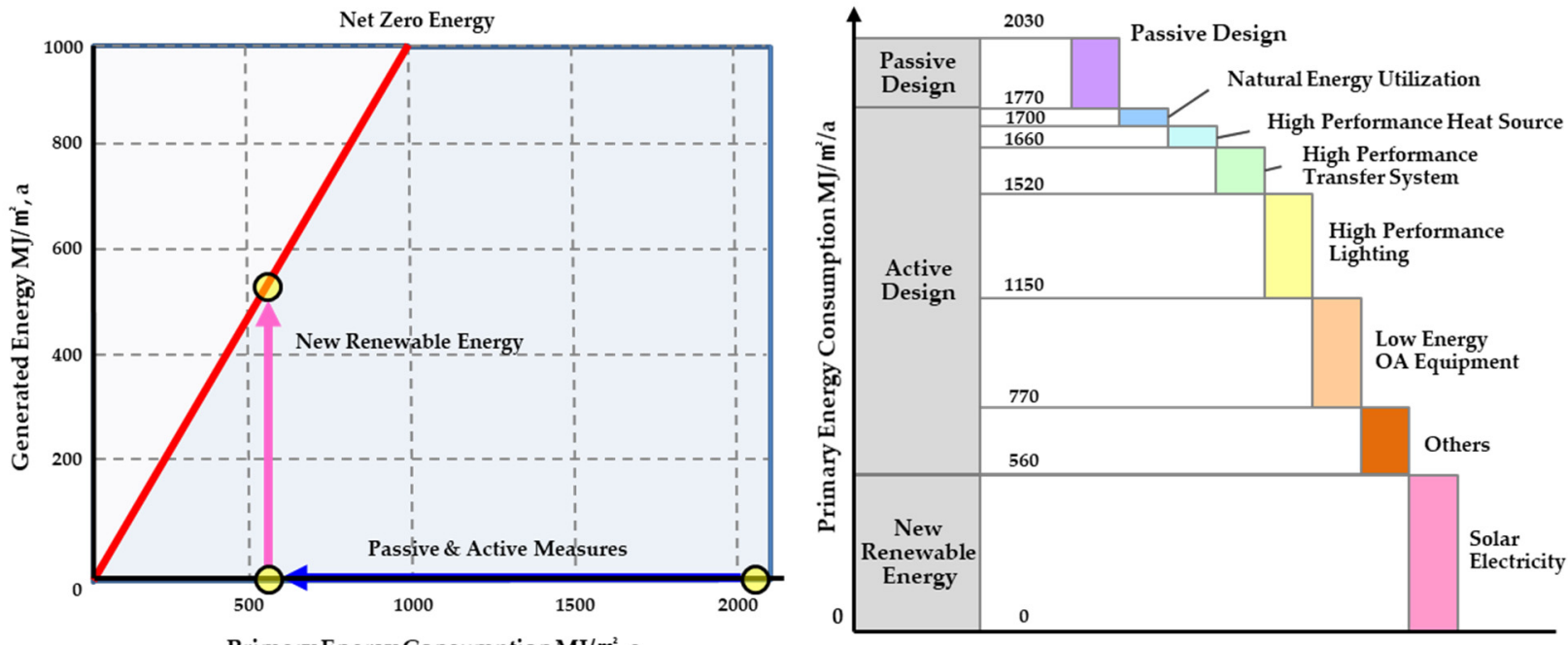

Primary Energy Consumption $\mathrm{MJ} / \mathrm{m}^{2}$, a

Figure 2. Concept of a zero-energy building.

Korea has implemented ZEB certification since 2017 and, from 2020, public buildings with a total floor area of $1000 \mathrm{~m}^{2}$ or more are legally mandated to acquire ZEB certification $[12,13]$. The scope for ZEB certification will be expanded to include private buildings and apartments from 2025, and all buildings with a total floor area of $500 \mathrm{~m}^{2}$ or more will be included from $2030[12,13]$. The ZEB grade is categorized into a total of five grades based on the ESR; the criteria and certification status for each ZEB grade are outlined in Table 1 [23].

Table 1. ZEB Grade Criteria and Certification Status by Grade in Korea.

\begin{tabular}{cccc}
\hline ZEB Grade & Grade Criteria & Certification Status & Certification Ratio \\
\hline grade 1 & ESR $\geq 100 \%$ & 27 cases & $2.26 \%$ \\
grade 2 & ESR $\geq 80 \%$ & 26 cases & $2.18 \%$ \\
grade 3 & ESR $\geq 60 \%$ & 83 cases & $6.95 \%$ \\
grade 4 & ESR $\geq 40 \%$ & 233 cases & $19.51 \%$ \\
grade 5 & ESR $\geq 20 \%$ & 825 cases & $69.10 \%$ \\
\hline
\end{tabular}

\subsection{ECO2 Program}

The software program, ECO2, used for ZEB evaluation of the buildings in Korea is developed and operated by the Korea Energy Agency (KEA), a ZEB operator. It utilizes the monthly method as its evaluation logic. ECO2 was developed in the early period 
using Microsoft visual basic for applications (VBA) as an Excel-based program. However, currently, ECO2 has been developed and is operated as a Windows-based program [24]. ECO2 performs ZEB evaluation by calculating the required energy and energy consumption of a building based on the monthly average weather data. The reference standards are ISO 13790 and DIN V 18599, and the monthly energy consumption for cooling, heating, hot water heating, ventilation, and lighting are evaluated with respect to the performance of the building. ECO2 is categorized into 20 types of use profiles according to the operation plan for each zone, and the energy demand based on the volume $\left(\mathrm{m}^{3}\right)$ of each zone is determined. Accordingly, the primary energy consumption and $\mathrm{CO}_{2}$ emissions per final unit area $\left(\mathrm{m}^{2}\right)$ through the installation of passive and active technology elements and new renewable energy are evaluated, and the ESR for ZEB classification is calculated [25]. The ECO2 use profile is composed as illustrated in Table 2 [26].

Table 2. ECO2 use profile information.

\begin{tabular}{cc}
\hline Index & Evaluation Contents \\
\hline Use profile & $\begin{array}{c}\text { Classified into } 20 \text { categories according to the operation plan for each zone } \\
\text { Residential space, small office, large office (over } 30 \mathrm{~m}^{2} \text { ), conference room, auditorium, cafeteria, restroom, } \\
\text { rest space (rest area, snack bar, etc.), attached space (lobby, hallway, etc.), storage room, information } \\
\text { technology office, kitchen, hospital patient room, hotel room, classroom, lecture hall, store, exhibition } \\
\text { room, reading room, fitness facility }\end{array}$ \\
Equipment operation time, set demand amount (hot water supply, lighting, etc.), human and auxiliary \\
equipment heat source, set temperature for cooling and heating, number of days used per month, \\
correction coefficient for each use category
\end{tabular}

The ESR is the ratio of the primary energy consumption to the primary energy production of a building. The energy production is calculated by subtracting the energy required for energy production from the energy produced through a new renewable energy system, whereas the energy consumption is calculated as the sum of the primary energy consumption and production per unit area [27]. This can be checked at the completion stage of the evaluation using ECO2. The ESR calculation formula is presented in Equation (1) [25].

$$
\text { Energy Self }- \text { Sufficiency rate }(\%)=\frac{\text { Primary Energy Production }{ }^{1)}}{\text { Primary Energy Consumption } \left.{ }^{2}\right)} \times 100 \text {, }
$$

(1) $\quad \Sigma\{($ New renewable energy production-energy required for new renewable energy production) $\times$ primary energy conversion coefficient $\}$

(2) Primary energy consumption per unit area + primary energy production per unit area.

Primary energy refers to the energy that can be obtained directly from nature without undergoing any transformation or processing. Because the energy used in a building is the transformed or processed form of the primary energy, it is calculated by multiplying the primary energy produced by the primary energy conversion coefficient. For each energy source, the primary energy conversion coefficients are listed in Table 3 [26].

Table 3. Primary energy conversion coefficient for each type of energy source.

\begin{tabular}{ccccc}
\hline Energy Source & Gas & Electricity & District Heating & District Cooling \\
\hline Primary energy conversion coefficient & 1.1 & 2.75 & 0.728 & 0.937 \\
\hline
\end{tabular}

Energy production refers to the energy generated in buildings through new renewable energy systems [28]. The types of new renewable energy include solar, geothermal, ocean, bioenergy, wind, and fuel cells. However, in this study, energy types such as ocean, bioenergy, and wind energy, which cannot be applied due to the characteristics of the site, are excluded; photovoltaic (PV) systems, building integrated photovoltaic (BIPV) 
systems, geothermal systems, and fuel cells that are mainly applied in buildings are the evaluation targets.

\subsection{Literature Review and a Comparison of the Present and Existing Studies}

Existing literature and research trends mainly target the primary energy consumption (i.e., the denominator of equation) (1); these studies include proposing optimal passive technology elements and methodology [15], minimizing the energy consumption and analyzing the energy behavior [16], proposing a ZEB technology package, analysis of passive and active technology elements [29], and ESR analysis of PV for residential buildings [30].

However, the present study targets the primary energy production (i.e., the numerator of Equation (1)), and facilitates the prediction of ESR and construction costs of new types of renewable energy by targeting small- and medium-sized public office buildings. Reliability is secured by selecting and evaluating the average model of three ZEB cases; thus, the building-related laws and ECO2 logic used in the actual work are applied, and different building characteristics can be considered. Finally, by deriving the ESR calculation formula for each major type of new and renewable energy, and verifying the error rate, a differentiation is achieved, which can be immediately used by construction stakeholders (building owner, architect, and builder) in actual work. Table 4 illustrates how the present study differs from the existing research.

Table 4. Differences between existing research and this study.

\begin{tabular}{|c|c|c|c|}
\hline Authors & Title & Main Contents & Differences in This Study \\
\hline $\begin{array}{l}\text { Bargues, J.L.; Vivancos, J.L.; } \\
\text { Gisbert, P.; Guillem, M. }\end{array}$ & $\begin{array}{l}\text { Zero-Energy Building } \\
\text { Integrated Planning } \\
\text { Methodology for Office } \\
\text { Building Considering Passive } \\
\text { and Active Environmental } \\
\text { Control Method. } \\
\text { Analysis of the Impact of } \\
\text { Different Variables on the } \\
\text { Energy Demand in } \\
\text { Office Buildings. } \\
\text { Development of a passive and } \\
\text { active technology package } \\
\text { standard and database for } \\
\text { application to zero energy } \\
\text { buildings in South Korea }\end{array}$ & $\begin{array}{l}\text { - Derive a design } \\
\text { methodology for ZEB. } \\
\text { - Analyze the passive } \\
\text { technology elements. } \\
\text { - Minimize energy } \\
\text { consumption. } \\
\text { - Analyze the energy behavior } \\
\text { of the office building. } \\
\text { - Propose a ZEB technology } \\
\text { package. } \\
\text { - Propose passive and active } \\
\text { technology packages, } \\
\text { modules, and } \\
\text { material performance. } \\
\text { - Energy consumption } \\
\text { analysis of residential } \\
\text { buildings. } \\
\text { - ESR analysis of PV among } \\
\text { the renewable energy types. }\end{array}$ & $\begin{array}{l}\text { - Analysis of passive and } \\
\text { active technology elements } \\
\text { through ZEB cases. } \\
\text { · Utilization of laws and ECO2 } \\
\text { logic that can be used in } \\
\text { actual work. } \\
\text { - Selection of target buildings } \\
\text { (Small and medium-sized } \\
\text { public office building) and } \\
\text { standard model development. } \\
\text { - Derivation of a major new } \\
\text { renewable energy (PV, BIPV, } \\
\text { Geothermal, and Fuelcell } \\
\text { systems). } \\
\text { - ESR and construction cost } \\
\text { analysis and ESR prediction } \\
\text { formula derivation. }\end{array}$ \\
\hline
\end{tabular}

\section{Materials and Methods}

For ESR and economic analysis, three ZEB cases were selected among the public office buildings in the Seoul metropolitan area (Seoul, Gyeonggi-do) in Korea. In terms of the building size, small- and medium-sized buildings with a total floor area of approximately $3000 \mathrm{~m}^{2}$, in which construction costs are involved when new renewable energy systems are included, were selected for analysis. The flow chart for the methods ESR and construction cost analysis of each new renewable energy type is depicted in Figure 3.

\subsection{Standard-Model Design}

To develop a new standard model with the average value of the passive and active technology elements of the three ZEB cases, the passive technology elements in the construction area and the active ones in the machinery and electrical equipment area were 
selected for each zone required by the ECO2 program [30,31]. The passive technology elements in the construction include the area of the wall, floor, and roof, which mainly correspond to the building envelope area and floor area, and the directions and factors that can affect the U-value of each part. The active technology elements in the machinery and electrical system include the capacity $(\mathrm{kW})$ of the equipment that can affect cooling, heating, hot water heating, ventilation, and lighting density [32-34]. Table 5 lists the data of the three ZEB cases and results of the standard model.

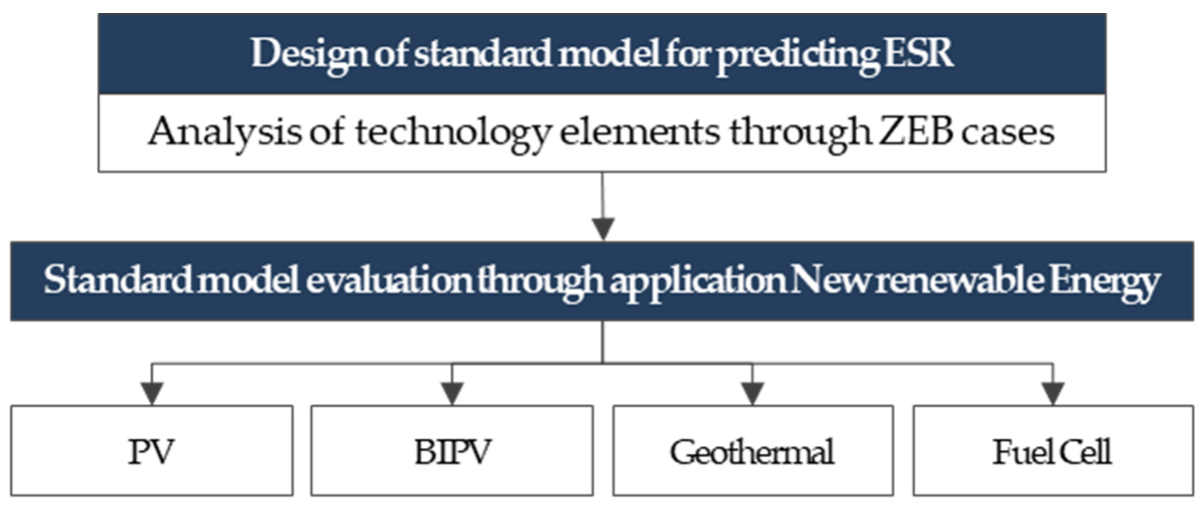

\section{ESR and Construction cost analysis by New renewable Energy type}

\section{Derivation of ESR calculation formula}

ESR and Construction cost analysis per $1 \mathrm{~kW}$ of capacity

Figure 3. Flow chart for the methods ESR and construction cost analysis of each new renewable energy type.

\subsection{ESR and Construction Cost Analysis}

Using the data from the standard model (Table 4), new renewable energy systems such as the PV, BIPV, geothermal, and fuel cell systems were applied to analyze the ESR and construction cost according to the capacity increase, through the ECO2 program. The data from a new renewable energy company in Korea were used as references for the data of each type of new renewable energy, such as the solar module, geothermal heat pump, and fuel cell, and construction cost, for estimating the required values [35-37]. Additionally, for the PV and BIPV systems, which require the module installation area, the number of required modules and the installation area were analyzed.

\subsubsection{Photovoltaic (PV) System}

For the PV system, the slope of the applied solar panel module was $45^{\circ}$, the orientation was south, and the module type was rear ventilating. A monocrystalline solar panel module with a dimension of $2163 \times 1030 \times 35 \mathrm{~mm}$, capacity of $460 \mathrm{~W}$, and efficiency of $20.0 \%$ was used. Hence, approximately 2.07 modules need to be installed per $1 \mathrm{~kW}$ of capacity, and the required installation area is approximately $4.599 \mathrm{~m}^{2}$ [35].

The ESR analysis results of the PV system, based on the standard model, using the $\mathrm{ECO} 2$ program, indicate an increase in the average primary energy production to $1.1 \mathrm{kWh} / \mathrm{m}^{2}$ and an average ESR of $0.54 \%$ per $1 \mathrm{~kW}$, demonstrating a constant increase. To achieve an ESR of $20 \%$ or higher, corresponding to ZEB grade 5, a capacity of $37 \mathrm{~kW}$ is required for which the required PV system installation area is approximately $170.19 \mathrm{~m}^{2}$, and the construction cost is 80,401 USD. To achieve an ESR of $100 \%$ or higher, corresponding to ZEB grade 1, a capacity of $183 \mathrm{~kW}$ is required, for which the required installation area is approximately $841.77 \mathrm{~m}^{2}$ and the construction cost is 397,659 USD. 
Table 5. ZEB cases and standard model data.

\begin{tabular}{|c|c|c|c|c|c|}
\hline \multicolumn{2}{|c|}{ Technology Elements } & Case-1 (a) & Case-2 (b) & Case-3 (c) & $\begin{array}{l}\text { Standard Model } \\
\{(a)+(b)+(c)\} \div 3\}\end{array}$ \\
\hline \multicolumn{2}{|c|}{ Usage } & $\begin{array}{l}\text { Public office } \\
\text { building }\end{array}$ & $\begin{array}{l}\text { Public office } \\
\text { building }\end{array}$ & $\begin{array}{l}\text { Public office } \\
\text { building }\end{array}$ & $\begin{array}{l}\text { Public office } \\
\text { building }\end{array}$ \\
\hline \multicolumn{2}{|c|}{ Total floor area $\left(\mathrm{m}^{2}\right)$} & 2803.12 & 3630.84 & 2529.01 & 2987.66 \\
\hline \multicolumn{2}{|c|}{ Aspect ratio of the plane } & 1:2.908 & 1:1.836 & 1:1.023 & 1:1.922 \\
\hline \multicolumn{2}{|c|}{ Size } & $\begin{array}{l}4 \text { floors above } \\
\text { ground, } 1 \text { floor } \\
\text { underground }\end{array}$ & $\begin{array}{l}4 \text { floors above } \\
\text { ground, } 2 \text { floors } \\
\text { underground }\end{array}$ & $\begin{array}{l}3 \text { floors above } \\
\text { ground, } 1 \text { floor } \\
\text { underground }\end{array}$ & $\begin{array}{l}4 \text { floors above } \\
\text { ground, } 1 \text { floor } \\
\text { underground }\end{array}$ \\
\hline \multicolumn{2}{|c|}{ Floor area of insulation space $\left(\mathrm{m}^{2}\right)$} & 1939.58 & 2551.60 & 1755.00 & 2082.06 \\
\hline \multirow{5}{*}{$\begin{array}{l}\text { Floor area by use } \\
\qquad\left(\mathrm{m}^{2}\right)\end{array}$} & Work space & 711.16 & 620.06 & 523.42 & 618.21 \\
\hline & Service facilities & 442.73 & 875.96 & 598.66 & 639.12 \\
\hline & Communal area & 614.76 & 767.68 & 395.89 & 592.78 \\
\hline & Sanitary facilities & 143.33 & 178.39 & 142.95 & 154.89 \\
\hline & Warehouse & 27.60 & 109.51 & 94.08 & 77.06 \\
\hline \multicolumn{2}{|c|}{ Window-to-wall ratio } & $22.26 \%$ & $26.35 \%$ & $25.54 \%$ & 24.72 \\
\hline \multirow{5}{*}{$\begin{array}{l}\text { Exterior wall area } \\
\text { by direction }\left(\mathrm{m}^{2}\right)\end{array}$} & Eastward & 232.97 & 332.09 & 363.04 & 309.37 \\
\hline & Westward & 270.39 & 430.77 & 311.68 & 337.61 \\
\hline & Southward & 522.87 & 521.56 & 283.40 & 442.61 \\
\hline & Northward & 495.64 & 711.84 & 299.81 & 502.43 \\
\hline & Eastward & 21.78 & 102.97 & 110.35 & 78.37 \\
\hline \multirow{3}{*}{$\begin{array}{l}\text { Window area by } \\
\text { direction }\left(\mathrm{m}^{2}\right)\end{array}$} & Westward & 66.92 & 79.41 & 100.49 & 82.27 \\
\hline & Southward & 203.57 & 307.25 & 163.40 & 224.74 \\
\hline & Northward & 143.40 & 224.75 & 103.06 & 157.07 \\
\hline \multicolumn{2}{|c|}{ Roof area of top floor $\left(\mathrm{m}^{2}\right)$} & 694.07 & 786.27 & 590.61 & 690.32 \\
\hline \multicolumn{2}{|c|}{ Floor area of bottom floor $\left(\mathrm{m}^{2}\right)$} & 694.07 & 786.27 & 590.61 & 690.32 \\
\hline \multirow{4}{*}{$\begin{array}{c}\text { Average U-value } \\
\text { by part } \\
\left(\mathrm{W} / \mathrm{m}^{2} \cdot \mathrm{K}\right)\end{array}$} & Exterior wall & 0.213 & 0.214 & 0.135 & 0.187 \\
\hline & Window and door & 1.399 & 1.333 & 1.392 & 1.375 \\
\hline & Roof & 0.170 & 0.129 & 0.083 & 0.127 \\
\hline & Floor & 0.166 & 0.164 & 0.142 & 0.157 \\
\hline \multirow{2}{*}{\multicolumn{2}{|c|}{ Cooling and heating system }} & EHP 102 kW & EHP 124 kW & EHP 91.4 kW & EHP 105.8 kW \\
\hline & & GHP 302 kW & GHP 294.4 kW & GHP 190 kW & GHP 262.1 kW \\
\hline \multicolumn{2}{|c|}{ Hot water heating system } & $\begin{array}{l}\text { gas-fired water } \\
\text { heater }(84 \mathrm{~kW})\end{array}$ & $\begin{array}{l}\text { electric water } \\
\text { heater }(34 \mathrm{~kW})\end{array}$ & $\begin{array}{l}\text { gas-fired water } \\
\text { heater }(112 \mathrm{~kW})\end{array}$ & $\begin{array}{l}\text { gas-fired water } \\
\text { heater }(93 \mathrm{~kW})\end{array}$ \\
\hline \multicolumn{2}{|c|}{$\begin{array}{l}\text { Primary Energy Conversion Coefficient } \\
\text { (Gas: 1.1, Electricity: } 2.75 \text { ) }\end{array}$} & $92.4 \mathrm{~kW}$ & $93.5 \mathrm{~kW}$ & $123.2 \mathrm{~kW}$ & $103 \mathrm{~kW}$ \\
\hline \multicolumn{2}{|c|}{ Ventilation system } & $\begin{array}{l}\text { energy recovery } \\
\text { ventilator(22ea) }\end{array}$ & $\begin{array}{l}\text { energy recovery } \\
\text { ventilator(25ea) }\end{array}$ & $\begin{array}{l}\text { energy recovery } \\
\text { ventilator(16ea) }\end{array}$ & $\begin{array}{l}\text { energy recovery } \\
\text { ventilator(21ea) }\end{array}$ \\
\hline \multicolumn{2}{|c|}{ Lighting density } & $4.90 \mathrm{~W} / \mathrm{m}^{2}(\mathrm{LED})$ & $4.41 \mathrm{~W} / \mathrm{m}^{2}(\mathrm{LED})$ & $7.82 \mathrm{~W} / \mathrm{m}^{2}(\mathrm{LED})$ & $5.71 \mathrm{~W} / \mathrm{m}^{2}(\mathrm{LED})$ \\
\hline
\end{tabular}

\subsubsection{Building Integrated Photovoltaic (BIPV) System}

For the BIPV system, the slope of the applied solar panel module was $90^{\circ}$ (vertical), the orientation was south, and the module type was wall-mounted. The same module used in the PV system was adopted with the same type, size, capacity, and efficiency [35].

The ESR analysis results of the PV system, based on the standard model, indicate that the average primary energy production increases to $0.7 \mathrm{kWh} / \mathrm{m}^{2}$ and the average ESR is $0.34 \%$ per $1 \mathrm{~kW}$, demonstrating a constant increase. To achieve an ESR of $20 \%$ or higher, corresponding to ZEB grade 5, a capacity of $58 \mathrm{~kW}$ is required, for which the required installation area is approximately $266.79 \mathrm{~m}^{2}$ and the construction cost is 302,470 USD. To achieve an ESR of $100 \%$ or higher, corresponding to ZEB grade 1, a capacity of $289 \mathrm{~kW}$ is required, for which the required installation area is approximately $1329.35 \mathrm{~m}^{2}$, and the construction cost is $1,507,135$ USD. Compared to the values of the PV system, the required installation area is greater by approximately 1.6 times and the construction cost by approximately 3.8 times. 


\subsubsection{Geothermal System}

A geothermal heat pump was used in the geothermal system for heating and cooling. It included a scroll compressor and geothermal expansion tank, and the coefficient of performance (COP) was 3.6. For the range of the geothermal heat pump capacity, the capacity $(10-100 \%, 367.9 \mathrm{~kW})$ of the heating/cooling system of the standard model was applied [36].

The ESR analysis results of the geothermal system of the standard model indicate that the best ESR efficiency is achieved with a heating/cooling system capacity ratio ranging from $30-40 \%$, and the increase in ESR gradually reduces when the ratio is greater than this range. In addition, the ESR is $0 \%$ with a heating/cooling system capacity ratio of $10-20 \%$; even with that of $100 \%$, the ESR is $6.46 \%$, which is below the value corresponding to grade 5 (ESR of $20 \%$ ), the lowest ZEB grade. This is because the power consumption of the geothermal heat pump required to supply underground heat was excluded from the energy production calculation [32]. A construction cost of 491,514 USD is required for a heating/cooling system capacity ratio of $100 \%$.

\subsubsection{Fuel Cell System}

A power generation efficiency of $37 \%$ and heat generation efficiency of $90 \%$ were applied to the heat production by the cells of the fuel cell system [37]. The ESR analysis results of the fuel cell system of the standard model demonstrate an increase in the primary energy production to $2.73 \mathrm{kWh} / \mathrm{m}^{2}$ and an average ESR of $1.39 \%$ per $1 \mathrm{~kW}$. For a capacity installation of $6 \mathrm{~kW}$, the ESR is $8.4 \%$, and the construction cost is 182,000 USD. In the case of the fuel cell system, the increase in energy production with the increase in capacity $(\mathrm{kW})$ gradually decreases when the applied capacity is $3 \mathrm{~kW}$ or higher, and for an applied capacity of $6 \mathrm{~kW}$ or higher, the energy production no longer increases. The results of the ESR and construction cost analysis for each type of new renewable energy are outlined in Tables 6-10, and Figure 4.

Table 6. Result of the construction cost comparison for primary energy production per $1 \mathrm{kWh} / \mathrm{m}^{2}$.

\begin{tabular}{ccccc}
\hline Primary Energy Production & PV & BIPV & Geothermal & Fuel Cell \\
\hline $1 \mathrm{kWh} / \mathrm{m}^{2}$ & $1 \mathrm{~kW}, 1975 \mathrm{USD}$ & $1.43 \mathrm{~kW}, 7450 \mathrm{USD}$ & $62.5 \mathrm{~kW}, 38,997 \mathrm{USD}$ & $0.68 \mathrm{~kW}, 9523 \mathrm{USD}$ \\
Additional cost compared against PV & 1 times & 1.57 times & 19.7 times & 4.8 times \\
\hline
\end{tabular}

Table 7. Results of the ESR and construction cost analysis for the photovoltaic (PV) system.

\begin{tabular}{|c|c|c|c|c|c|c|c|}
\hline $\begin{array}{c}\text { Capacity } \\
(\mathrm{kWp})\end{array}$ & $\begin{array}{l}\text { Module } \\
\quad \text { (ea) }\end{array}$ & $\begin{array}{l}\text { Area } \\
\left(\mathrm{m}^{2}\right)\end{array}$ & $\begin{array}{c}\text { Primary Energy } \\
\text { Consumption } \\
\left(\mathbf{k W h} / \mathbf{m}^{2}\right)\end{array}$ & $\begin{array}{c}\text { Primary Energy } \\
\text { Production } \\
\left(\mathbf{k W h} / \mathbf{m}^{2}\right)\end{array}$ & ESR & $\begin{array}{l}\text { Construction } \\
\text { Cost } \\
\text { (USD) }\end{array}$ & ZEB Grade \\
\hline 18.52 & 38.37 & 85.18 & 203.7 & 20.37 & $10 \%$ & 40,241 & none \\
\hline 37.04 & 76.74 & 170.36 & 203.6 & 40.74 & $20 \%$ & 80,481 & grade 5 \\
\hline 55.56 & 115.11 & 255.55 & 203.6 & 61.11 & $30 \%$ & 120,722 & grade 5 \\
\hline 74.07 & 153.48 & 340.73 & 203.7 & 81.48 & $40 \%$ & 160,963 & grade 4 \\
\hline 92.59 & 191.85 & 425.91 & 203.7 & 101.85 & $50 \%$ & 201,204 & grade 4 \\
\hline 111.11 & 230.22 & 511.09 & 203.7 & 122.22 & $60 \%$ & 241,444 & grade 3 \\
\hline 129.63 & 268.59 & 596.28 & 203.6 & 142.59 & $70 \%$ & 281,685 & grade 3 \\
\hline 148.15 & 306.96 & 681.46 & 203.7 & 162.96 & $80 \%$ & 321,926 & grade 2 \\
\hline 166.67 & 345.33 & 766.64 & 203.7 & 183.33 & $90 \%$ & 362,167 & grade 2 \\
\hline 185.19 & 383.70 & 851.82 & 203.7 & 203.70 & $100 \%$ & 402,407 & grade 1 \\
\hline Average & 2.07ea $/ \mathrm{kW}$ & $2.22 / \mathrm{kW}$ & 203.7 & $1.1 / \mathrm{kW}$ & $0.54 \% / \mathrm{kW}$ & 2173 USD/kW & - \\
\hline
\end{tabular}

\subsubsection{Photovoltaic (PV) and Building Integrated Photovoltaic (BIPV) System}

Analysis of the ESR according to the type of new renewable energy (PV and BIPV systems) displayed a proportional relationship between the installation capacity and ESR. 
The ESR of the PV and BIPV systems in the standard model can be calculated using Equations (2) and (3):

$$
\begin{gathered}
\operatorname{ESR}_{\mathrm{PV}}(\%)=\text { Capacity } \times 0.54 \times \text { Total floor area for evaluation }\left(\mathrm{m}^{2}\right) \div 2987.66\left(\mathrm{~m}^{2}\right) \\
\operatorname{ESR}_{\mathrm{BIPV}}(\%)=\text { Capacity } \times 0.34 \times \text { Total floor area for evaluation }\left(\mathrm{m}^{2}\right) \div 2987.66\left(\mathrm{~m}^{2}\right)
\end{gathered}
$$

\begin{tabular}{|c|c|c|c|c|c|c|c|}
\hline \multirow{2}{*}{$\begin{array}{c}\text { Capacity } \\
(\mathrm{kWp})\end{array}$} & \multirow[b]{2}{*}{$\begin{array}{l}\text { Module } \\
\text { (ea) }\end{array}$} & \multirow[b]{2}{*}{$\begin{array}{l}\text { Area } \\
\left(\mathrm{m}^{2}\right)\end{array}$} & \multirow{2}{*}{$\begin{array}{l}\text { Primary Energy } \\
\text { Consumption } \\
\left(\mathrm{kWh} / \mathrm{m}^{2}\right)\end{array}$} & \multirow{2}{*}{$\begin{array}{c}\text { Primary Energy } \\
\text { Production } \\
\left(\mathrm{kWh} / \mathrm{m}^{2}\right)\end{array}$} & \multicolumn{3}{|c|}{ Construction } \\
\hline & & & & & ESR & $\begin{array}{c}\text { Cost } \\
\text { (USD) }\end{array}$ & ZEB Grade \\
\hline 29.09 & 60.27 & 133.79 & 203.6 & 20.36 & $10 \%$ & 151,682 & none \\
\hline 58.17 & 120.53 & 267.58 & 203.7 & 40.72 & $20 \%$ & 303,364 & grade 5 \\
\hline 87.26 & 180.80 & 401.37 & 203.6 & 61.08 & $30 \%$ & 455,046 & grade 5 \\
\hline 116.34 & 241.06 & 535.16 & 203.7 & 81.44 & $40 \%$ & 606,728 & grade 4 \\
\hline 145.43 & 301.33 & 668.95 & 203.5 & 101.80 & $50 \%$ & 758,410 & grade 4 \\
\hline 174.51 & 361.59 & 802.74 & 203.8 & 122.16 & $60 \%$ & 910,092 & grade 3 \\
\hline 203.60 & 421.86 & 936.53 & 203.8 & 142.52 & $70 \%$ & $1,061,774$ & grade 3 \\
\hline 232.69 & 482.12 & 1070.32 & 203.6 & 162.88 & $80 \%$ & $1,213,456$ & grade 2 \\
\hline 261.77 & 542.39 & 1204.11 & 203.8 & 183.24 & $90 \%$ & $1,365,138$ & grade 2 \\
\hline 290.86 & 602.66 & 1337.90 & 203.6 & 203.60 & $100 \%$ & $1,516,820$ & grade 1 \\
\hline Average & $2.07 \mathrm{ea} / \mathrm{kW}$ & $2.22 \mathrm{~m}^{2} / \mathrm{kW}$ & 203.7 & $0.7 / \mathrm{kW}$ & $0.34 \% / \mathrm{kW}$ & 5215 USD/kW & - \\
\hline
\end{tabular}

Table 8. Results of the ESR and construction cost analysis for the building integrated photovoltaic (BIPV) system.

\begin{tabular}{|c|c|c|c|c|c|c|}
\hline $\begin{array}{c}\text { Cooling and } \\
\text { Heating Capacity } \\
\text { Ratio }\end{array}$ & $\begin{array}{l}\text { Capacity } \\
(\mathbf{k W})\end{array}$ & $\begin{array}{l}\text { Primary Energy } \\
\text { Consumption } \\
\left(\mathrm{kWh} / \mathrm{m}^{2}\right)\end{array}$ & $\begin{array}{c}\text { Primary Energy } \\
\text { Production } \\
\left(\mathbf{k W h} / \mathrm{m}^{2}\right)\end{array}$ & ESR & $\begin{array}{l}\text { Construction Cost } \\
\text { (USD) }\end{array}$ & ZEB Grade \\
\hline $10 \%$ & 36.8 & 218.9 & 0 & $0 \%$ & 49,165 & none \\
\hline $20 \%$ & 73.6 & 198.8 & 0 & $0 \%$ & 98,330 & none \\
\hline $30 \%$ & 110.4 & 195.3 & 3.2 & $1.64 \%$ & 147,494 & none \\
\hline $40 \%$ & 147.2 & 195.1 & 6.5 & $3.33 \%$ & 196,659 & none \\
\hline $50 \%$ & 184.0 & 195.1 & 8.6 & $4.41 \%$ & 245,824 & none \\
\hline $60 \%$ & 220.7 & 195.1 & 9.9 & $5.08 \%$ & 294,855 & none \\
\hline $70 \%$ & 257.5 & 195.1 & 10.9 & $5.59 \%$ & 344,020 & none \\
\hline $80 \%$ & 294.3 & 195.1 & 11.6 & $5.95 \%$ & 393,185 & none \\
\hline $90 \%$ & 331.1 & 195.1 & 12.2 & $6.25 \%$ & 442,350 & none \\
\hline $100 \%$ & 367.9 & 195.1 & 12.6 & $6.46 \%$ & 491,514 & none \\
\hline Average & - & 197.87 & $0.034 / \mathrm{kW}$ & $0.016 \% / \mathrm{kW}$ & 1336 USD/kW & - \\
\hline
\end{tabular}

Table 9. Results of the ESR and construction cost analysis for the geothermal system.

\begin{tabular}{|c|c|c|c|c|c|}
\hline $\begin{array}{l}\text { Capacity } \\
(\mathbf{k W})\end{array}$ & $\begin{array}{c}\text { Primary Energy } \\
\text { Consumption } \\
\left(\mathrm{kWh} / \mathrm{m}^{2}\right)\end{array}$ & $\begin{array}{l}\text { Primary Energy Production } \\
\left(\mathrm{kWh} / \mathrm{m}^{2}\right)\end{array}$ & ESR & $\begin{array}{l}\text { Construction Cost } \\
\text { (USD) }\end{array}$ & ZEB Grade \\
\hline 1 & 199.6 & 6.8 & $3.41 \%$ & 26,000 & none \\
\hline 2 & 196.3 & 13.1 & $6.67 \%$ & 52,000 & none \\
\hline 3 & 193.6 & 15.2 & $7.85 \%$ & 78,000 & none \\
\hline 4 & 192.1 & 15.8 & $8.22 \%$ & 104,000 & none \\
\hline 5 & 191.1 & 16.2 & $8.48 \%$ & 130,000 & none \\
\hline 6 & 190.5 & 16.4 & $8.61 \%$ & 156,000 & none \\
\hline Average & 193.87 & $2.73 / \mathrm{kW}$ & $1.46 \% / \mathrm{kW}$ & $26,000 \mathrm{USD} / \mathrm{kW}$ & - \\
\hline
\end{tabular}

Table 10. Results of the ESR and construction cost analysis for the fuel cell system. 


\subsection{Derivation and Verification of the ESR Calculation Formula for Each Type of New} Renewable Energy

\subsubsection{Geothermal System}

In the geothermal system, there was no proportional relationship between the increase in the capacity and the ESR; therefore, Equation (4) was derived using the logarithmic trend line.

$$
\begin{aligned}
& \left.\operatorname{ESR}_{\text {Geothermal }}(\%)=\left\{0.031 \times \ln \left(\mathrm{X}^{1)}\right) \div 10\right)-0.0113\right\} \times \text { Total floor area for evaluation }\left(\mathrm{m}^{2}\right) \div 2987.66\left(\mathrm{~m}^{2}\right) \\
& \text { 1) } \mathrm{X}=\text { Cooling and Heating Capacity Ratio }(\%), 60 \leq \mathrm{X} \leq 100 .
\end{aligned}
$$

Based on the ESR calculated using Equation (4), depending on the cooling and heating capacity ratio, the following differences were observed: $1.30 \%(10 \%), 0.85 \%(20 \%)$, $0.47 \%(30 \%), 0.33 \%(40 \%), 0.72 \%(50 \%), 0.28 \%$ (60\%), $0.28 \%$ (70\%), $0.20 \%(80 \%), 0.11 \%$ $(90 \%)$, and $0.03 \%(100 \%)$. The values indicate that the lower the cooling and heating capacity ratio, the larger is the error range. However, according to the energy saving design standard in Korea, cooling and heating capacity ratios of $60 \%$ or higher are mandatory for public building $[38,39]$. Therefore, in the cooling and heating capacity ratio range of $60 \%$ or higher, where the percentage error is insignificant, Equation (4) can be used for the ESR prediction of geothermal systems in the design stage.

\subsubsection{Fuel Cell System}

In the case of the fuel cell system, there was no proportional relationship between the increase in the capacity and the ESR; therefore, Equation (5) was derived using the logarithmic trend line. When the ESR was calculated using Equation (5), depending on the capacity, the following differences were observed: $1.19 \%(1 \mathrm{~kW}), 0.08 \%(2 \mathrm{~kW})$, $0.10 \%(3 \mathrm{~kW}), 0.36 \%(4 \mathrm{~kW}), 0.74 \%(5 \mathrm{~kW})$, and $1.13 \%(6 \mathrm{~kW})$. The values demonstrate that the larger the capacity, the larger the error range. In addition, as per the information obtained from the Korea Energy Agency (KEA), the ECO2 program has a limitation wherein it does not recognize the electrical energy production of the fuel cell system as energy production but only recognizes hot water heating as energy production; hence, the installation capacity of the fuel cell system is significantly lower than those of the other types of new renewable energy $[31,40]$. When the ECO2 program is improved in the future and the electrical energy production of the fuel cell system is recognized and reflected in the ESR calculation, Equation (5) may change accordingly:

$$
\operatorname{ESR}_{\text {Feul cell }}(\%)=\{0.0287 \times \ln (\text { capacity })+0.0406\} \times \text { Total floor area for evaluation }\left(\mathrm{m}^{2}\right) \div 2987.66\left(\mathrm{~m}^{2}\right)
$$

\subsubsection{Total ESR Calculation}

The total ESR is calculated by adding the ESRs derived for each type of new renewable energy through Equations (2)-(5). Compared with the target ESR through final ESR calculation, it is possible to apply the optimal capacity of new renewable energy by additionally applying or partially reducing the new renewable energy. The total ESR calculation formula is provided in Equation (6).

$$
\mathrm{ESR}_{\text {Total }}(\%)=\mathrm{ESR}_{\mathrm{PV}}+\mathrm{ESR}_{\mathrm{BIPV}}+\mathrm{ESR}_{\text {Geothermal }}+\mathrm{ESR}_{\mathrm{Feul} \mathrm{cell}}
$$



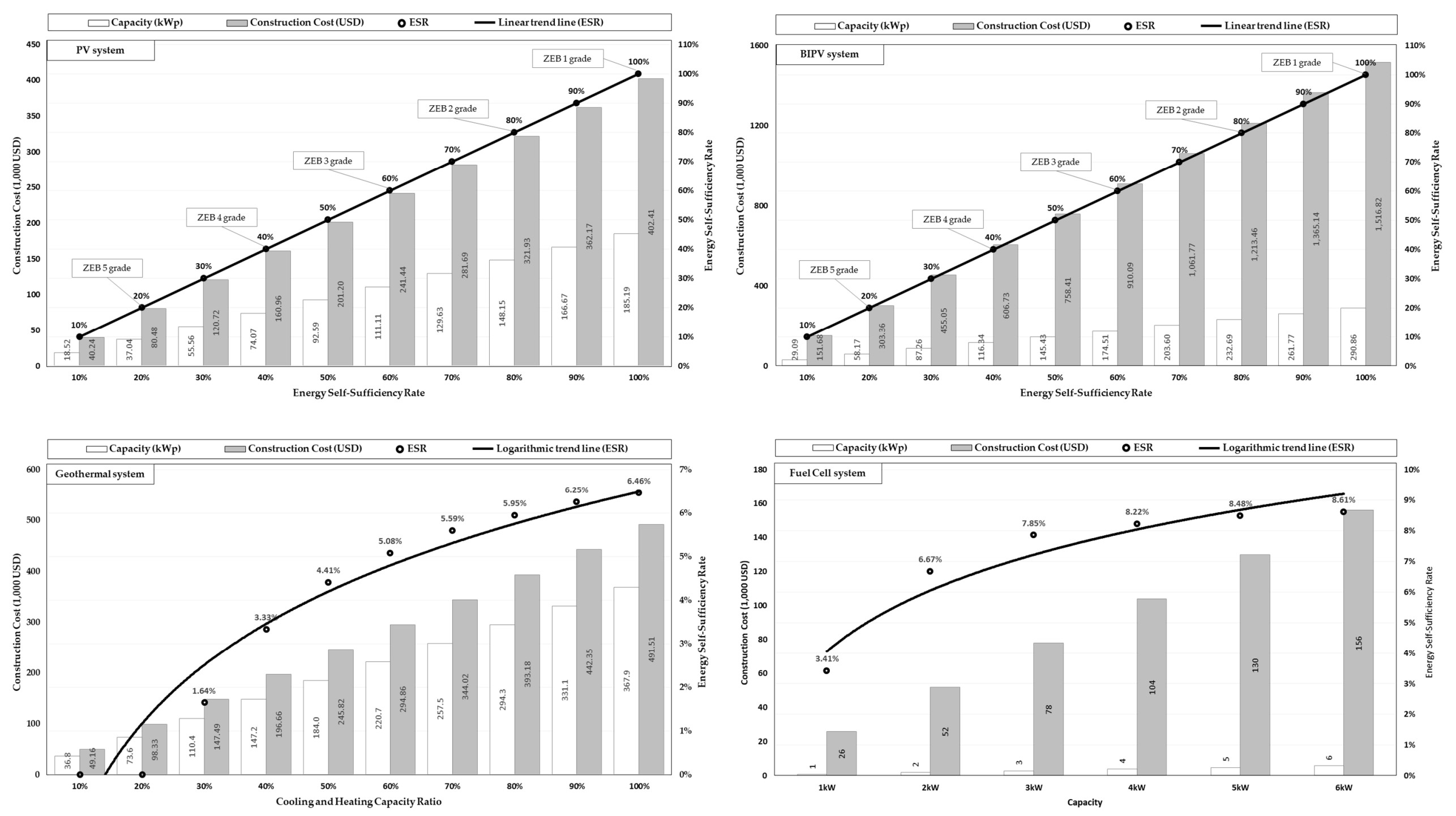

Figure 4. Results of the ESR and construction cost analysis for each type of new renewable energy. 


\subsubsection{Verification of the ESR Formulas and Economic Analysis Based on ZEB Cases}

To verify the derived ESR formula, the new renewable energy capacity and ESR applied to the three ZEB cases analyzed for the development of the standard model were compared. In addition, the ESR values calculated through the new renewable energy applied and those derived using Equations (2)-(5) were compared for three ZEB cases, for which the buildings were evaluated using ECO2 and have been designed, built, and completed. The difference between the values was in the range of $0.11-1.78 \%$, and the percentage error was $0.66-7.89 \%$. In addition, construction cost savings when PV, which had the best ESR efficiency and was most economical according to the analysis result of this study, is applied to the ZEB cases were compared to the construction costs of new renewable energy actually applied to the ZEB cases. Based on Tables 6-9 and using Equations (2)-(5), the new renewable energy system was converted to PV to make the ESRs the same as those applied to the ZEB cases. As a result, $56.46 \%$ of the construction cost is saved for Case 1, $83.33 \%$ for Case 2, and $45.46 \%$ for Case 3 . This is expected to allow the construction stakeholders to contribute to the new renewable energy design in the design stage. Verification of the ESR formulas and economic analysis results based on the ZEB cases are provided in Table 11.

Table 11. Verification of the ESR formulas and economic analysis based on ZEB cases.

\begin{tabular}{|c|c|c|c|c|}
\hline & tegory & Case-1 & Case-2 & Case-3 \\
\hline \multirow{6}{*}{ Case } & Total floor area & $2803.1 \mathrm{~m}^{2}$ & $3630.8 \mathrm{~m}^{2}$ & $2529.0 \mathrm{~m}^{2}$ \\
\hline & \multirow{3}{*}{ New Renewable Energy } & & PV 28 kW, Geothermal & \\
\hline & & PV 16.2 kW & $290 \mathrm{~kW}$ & PV 45 kW \\
\hline & & Fuel cell 5 kW & (Cooling and Heating & Fuel cell $6 \mathrm{~kW}$ \\
\hline & ESR (a) & $16.75 \%$ & $22.55 \%$ & $29.10 \%$ \\
\hline & Construction cost (c) & 165,202.6 USD & 448,284 USD & 253,785 USD \\
\hline \multirow{3}{*}{ Formula } & ESR (b) & $16.86 \%$ & $24.33 \%$ & $28.82 \%$ \\
\hline & \multirow{2}{*}{ Construction cost (d) } & $71,926.3$ & $74,751.2$ & $138,420.1$ \\
\hline & & (PV $33.1 \mathrm{~kW})$ & $(\mathrm{PV} 34.4 \mathrm{~kW})$ & $(\mathrm{PV}$ 63.7kW) \\
\hline \multirow{3}{*}{\multicolumn{2}{|c|}{$\begin{array}{c}\text { Error }(b-a) \\
\text { Percent error }((b-a) / a) \times 100) \\
\text { Construction cost saving ratio }((d-c) / d \times 100)\end{array}$}} & $0.11 \%$ & $1.78 \%$ & $-0.28 \%$ \\
\hline & & $0.66 \%$ & $7.89 \%$ & $0.96 \%$ \\
\hline & & $56.46 \%$ & $83.33 \%$ & $45.46 \%$ \\
\hline
\end{tabular}

\section{Discussion}

Equations (2)-(5) were derived based on the ZEB cases and the standard model for ESR prediction; they may not serve as universal equations applicable for all evaluation targets. In particular, if there is a difference in the size, cooling, heating, and hot water heating capacity, depending on the characteristics of the construction project, the error may increase; therefore, it is recommended to apply the derived ESR formulas to small and medium-sized public business facilities having similar characteristics.

For PV and BIPV systems, in particular, module installation is mainly needed on the roof or exterior wall, window, and door area southward, and the installation area and ESR need to be considered. The results demonstrate that when the PV system is installed in all the roof areas of the standard model, an ESR of $80 \%$ (equivalent to ZEB grade 2) can be achieved, and when the BIPV system is installed in all the areas of the southward exterior wall, windows, and doors, an ESR of $40 \%$, (equivalent to ZEB grade 4) can be achieved. However, in the case of geothermal and fuel cell systems, even with a cooling and heating capacity ratio of $100 \%$ or with a hot-water heating consumption ratio of $100 \%$, the ESR is only $6.46 \%$ and $8.61 \%$, respectively. Therefore, in order to achieve a good ZEB grade and high ESR, other new renewable energy systems such as PV or BIPV should be installed. Thus, to ensure high ESR, PV and BIPV systems should be considered first, and 
if additional ESR is required due to insufficient module installation area, the utilization of geothermal or fuel cell systems should be considered.

This study was conducted to calculate the ESR by selecting the primary energy production, which is the numerator in Equation (1), as the target. However, it is important to reduce the primary energy consumption, the denominator in Equation (1), for improving the ESR for the same renewable energy applied. To this end, a standard model design is needed to attain an economical ZEB that consumes less and produces less, rather than a high-consumption ZEB that consumes a lot and produces a lot.

Furthermore, although this study was conducted on $\mathrm{CO}_{2}$, which is required for net zero and ZEB in the building sector, it will be important to consider other gases, such as NOx, SOx, and CO, in addition to other environmental effects during the entire building process to realize truly energy-independent buildings. In particular, it is determined that energy saving systems that can accumulate energy should be considered when the ESR exceeds 100\%. This must be supported by continuous research and revisions to the policy in the future. Therefore, it is expected that all gases will be taken into consideration to evaluate the total energy; life cycle assessment (LCA) will be considered, and economical, truly net zero buildings can then be realized.

\section{Conclusions}

This study aims to contribute to the optimal design of new renewable energy systems from the design stage and predict the construction cost to assist the construction industry by developing a standard model for small and medium-sized public office buildings in the Seoul metropolitan area (Seoul, Gyeonggi-do) in Korea. Based on a standard model, the ESR and construction cost were analyzed for each type of major new renewable energy, and the following conclusions were derived after verifying the percentage error.

1. The ESR and construction cost analysis results of the photovoltaic (PV) system indicated that the ESR per $1 \mathrm{kWp}$ was $0.54 \%$, and the construction cost was $2173 \mathrm{USD}$. The ESR displayed a constant rate of increase with the increase in capacity, and Equation (2) was derived accordingly.

2. For the BIPV system, the obtained ESR per $1 \mathrm{kWp}$ was $0.34 \%$, and the construction cost was 5215 USD. The ESR displayed a constant rate of increase with the increase in capacity, and Equation (3) was derived accordingly.

3. For the geothermal system, the obtained ESR per $1 \mathrm{~kW}$ was $0.016 \%$ and the construction cost was 1336 USD. The rate of increase of the ESR decreased with the increase in the capacity, and Equation (4) was derived using a logarithmic trendline.

4. For the fuel cell system, the ESR per $1 \mathrm{~kW}$ was $1.46 \%$, and the construction cost was 26,000 USD. The rate of increase of the ESR decreased with the increase in the capacity, and Equation (5) was derived using a logarithmic trendline.

5. On comparing the ESR of the Korean ZEB cases with the ESR obtained using the derived formulas, the maximum ESR difference was $1.78 \%$, and the maximum percentage error was $7.89 \%$.

Author Contributions: All the authors contributed substantially to all parts of this study. All authors have read and agreed to the published version of the manuscript.

Funding: This work was supported by the National Research Foundation of Korea (NRF) grant funded by the Korea government (MSIT) (grant number 2015R1A5A1037548); and the Korea Agency for Infrastructure Technology Advancement (KAIA) grant funded by the Ministry of Land, Infrastructure and Transport (grant number 21CTAP-C152276-03).

Institutional Review Board Statement: Not applicable.

Informed Consent Statement: Not applicable.

Data Availability Statement: Not applicable.

Conflicts of Interest: The authors declare no conflict of interest. 


\section{References}

1. Rogelj, J.; Shindell, D.; Jiang, K.; Fifita, S.; Forster, P.; Ginzburg, V.; Handa, C.; Kheshgi, H.; Kobayashi, S.; Kriegler, E.; et al. Mitigation Pathways Compatible with $1.5^{\circ} \mathrm{C}$ in the Context of Sustainable Development. In Global Warming of $1.5^{\circ} \mathrm{C}$. An IPCC Special Report on the Impacts of Global Warming of $1.5^{\circ} \mathrm{C}$ above Pre-Industrial Levels and Related Global Greenhouse Gas Emission Pathways, in the Context of Strengthening the Global Response to the Threat of Climate Change, Sustainable Development, and Efforts to Eradicate Poverty; Masson-Delmotte, V., Zhai, P., Pörtner, H.-O., Roberts, D., Skea, J., Shukla, P.R., Pirani, A., Moufouma-Okia, W., Péan, C., Pidcock, R., et al., Eds.; Intergovernmental Panel on Climate Change (IPCC): Geneva, Switzerland, 2018; in press.

2. Rogelj, J.; Den Elzen, M.; Höhne, N.; Fransen, T.; Fekete, H.; Winkler, H.; Schaeffer, R.; Sha, F.; Riahi, K.; Meinshausen, M. Paris Agreement climate proposals need a boost to keep warming well below $2{ }^{\circ} \mathrm{C}$. Nature 2016, 534, 631-639. [CrossRef]

3. European Commission Climate Strategies \& Targets. Available online: https://ec.europa.eu/clima/policies/strategies/2030_en (accessed on 30 June 2021).

4. Haas, T.; Sander, H. Decarbonizing Transport in the European Union: Emission Performance Standards and the Perspectives for a European Green Deal. Sustainability 2020, 12, 8381. [CrossRef]

5. Stokes, L.C. Short Circuiting Policy: Interest Groups and the Battle over Clean Energy and Climate Policy in the American State; Oxford University Press: New York, NY, USA, 2020; ISBN 978-0-19-007426-5.

6. Park, Y.S.; Gang, G.S.; Jang, Y.U.; Kim, S.H.; Lee, H.J. The Direction and Implications of the International Community's Carbon-Neutral Policy; Korea Institute for International Economic Policy KIEP: Sejong, Korea, 2021; Volume 1, pp. 1-15.

7. Dias, B.D. Beyond Sustainability-Biophilic and Regenerative Design in Architecture. Eur. Sci. J. 2015, 11, 1857-7881.

8. Savaresi, A. The Paris agreement: A new beginning? J. Energy Nat. Resour. Law 2016, 34, 16-26. [CrossRef]

9. Korean New Deal. Available online: https://www.knewdeal.go.kr (accessed on 30 July 2021).

10. Lee, J.-H.; Woo, J. Green New Deal Policy of South Korea: Policy Innovation for a Sustainability Transition. Sustainability 2020, 12, 10191. [CrossRef]

11. Yoon, K. Discourse of the Post-COVID 19 New Deal in South Korea. East Asia 2021. [CrossRef] [PubMed]

12. Kim, Y.; Yu, K. Study on the Certification Policy of Zero-Energy Buildings in Korea. Sustainability 2020, 12, 5172. [CrossRef]

13. Zero Energy Building. Available online: https:/ / zeb.energy.or.kr/BC/BC02/BC02_01_001.do (accessed on 30 July 2021).

14. Kim, Y.; Yu, K. Study on Policy Marking of Passive Level Insulation Standards for Non-Residential Buildings in South Korea. Sustainability 2018, 10, 2554. [CrossRef]

15. Lee, S.M.; Parn, S.H. Zero-Energy Building Integrated Planning Methodology for Office Building Considering Passive and Active Environmental Control Method. Appl. Sci. 2021, 11, 3686. [CrossRef]

16. Bargues, J.L.; Vivancos, J.L.; Gisbert, P.; Guillem, M. Analysis of the Impact of Different Variables on the Energy Demand in Office Buildings. Sustainability 2020, 12, 5347. [CrossRef]

17. Taherahmadi, J.; Noorollahi, Y.; Panahi, M. Toward comprehensive zero energy building definitions: A literature review and recommendations. Int. J. Sustain. Energy 2020, 40, 120-148. [CrossRef]

18. Wang, S.J.; Tae, S.H.; Kim, R.H. Development of a Green Building Materials Integrated Platform Based on Materials and Resources in G-SEED in South Korea. Sustainability 2019, 11, 6532. [CrossRef]

19. Wright, G.; Klingenberg, K. Climate-Specific Passive Building Standards; US Department of Energy, Building America Program, Office of Energy Efficiency and Renewable Energy: Washington, DC, USA, 2015.

20. Hongze, L.; Fengyun, L.; Di, S.; Xinhua, Y.; Jianfei, S. Carbon Emission Intensity, Economic Development and Energy Factors in 19 G20 Countries: Empirical Analysis Based on a Heterogeneous Panel from 1990 to 2015. Sustainability 2018, $10,2330$.

21. Heryadi, M.D.; Hartono, D. Energy Efficiency, Utilization of Renewable Energies, and Carbon Dioxide Emission: Case Study of G20 Countries. Int. Energy. J. 2016, 16, 143-152.

22. Lim, H.S. Design and Performance Evaluation of Thermoelectric Radiant Cooling and Heating Panel. Ph.D. Thesis, Hanyang University, Seoul, Korea, 2020.

23. Zero Energy Building. Available online: https:/ / zeb.energy.or.kr/BC/BC03/BC03_06_001.do (accessed on 30 July 2021).

24. Korea Energy Agency. Available online: https://building.energy.or.kr/build/CC/CCIRList.do?page=426 (accessed on 30 July 2021).

25. Ministry of Land, Infrastructure and Transport. Rules for Building Energy Efficiency Rating Certification and Zero Energy Building Certification; Ministry of Government Legislation: Sejong, Korea, 2020. Available online: https://law.go.kr/lsSc.do?section= \&menuId=1\&subMenuId=15\&tabMenuId=81\&eventGubun=060101\&query=\%EC $\% 97 \% 90 \% E B \% 84 \% 88 \% E C \% A 7 \% 80 \% E D \%$ 9A\%A8\%EC\%9C\%A8\%EB\%93\%B1\%EA\%B8\%89\#undefined (accessed on 30 July 2021).

26. Korea Energy Agency. Building Energy Efficiency Rating Certification System Operational Regulations; Public Institutions: Ulsan, Korea, 2020; Available online: https:/ / beec.energy.or.kr/BC/BC04/BC04_05_002.do?no=5 (accessed on 30 July 2021).

27. Mun, J.H.; Kim, J.C. A Study on the Improvement of Energy Self-Sufficiency Rate for Obtaining Zero Energy Building Certification. J. Kor. Inst. Illum Electr. Install. Eng. 2018, 32, 27-32.

28. Kim, M.R.; Lee, K.J.; Park, H.S. A study on the cases of new renewable energy applied buildings in Korea and Germany-Focused on solar and geothermal energy cases. Archit. Inst. Korea 2012, 28, 29-37.

29. Sung, U.J.; Kim, S.H. Development of a Passive and Active Technology Package Standard and Database for Application to Zero Energy Building in South Korea. Energies 2019, 12, 1700. [CrossRef] 
30. Yoon, J.H. The Role and Practical Contribution of Renewable Energy Technologies in Actual Zero Energy Building. Mag. Kor. Solar Energy Soc. 2016, 14, 24-32.

31. Marszal, A.J.; Heiselberg, P.; Bourrelle, J.S.; Musall, E.; Voss, K.; Sartori, I.; Napolitano, A. Zero Energy Building-A review of definitions and calculation methodologies. Energy Build. 2011, 43, 971-979. [CrossRef]

32. Lee, D.Y.; Yoo, D.C.; Jo, S.Y.; Park, C.Y.; Jang, H.I. A Study on the Average Performance and Reference Model depending on Passive and Active Factor for Zero Energy Building Certification in Smart City-Focused on Education and Research Facilities and Office. J. Kor. Inst. Arch. Sustain. Environ. Build. Syst. 2020, 14, 387-400.

33. Shim, H.S.; Lee, S.J. A Study on the Increase in Construction Cost for Zero Energy Building. J. Kor. Acad.-Indus. Coop. Soc. 2021, 22, 603-613.

34. Kim, J.H.; Jo, S.Y.; Kim, C.M.; Jang, H.I.; Kim, S.S. Analysis of Design Parameters Affecting Zero Energy Buildings based on the Building Energy Efficiency Rating Certified Buildings-Focused on Educational Research Facilities. J. Kor. Inst. Arch. Sustain. Environ. Build. Syst. 2018, 12, 387-399.

35. HANHWA Solutions. Available online: https://www.q-cells.com/en/main/products/solar_panels/G9/Q.PEAK-DUO-XL-G9 .html (accessed on 30 July 2021).

36. SAMSUNG. Available online: https://www.samsung.com/sec/business/dvms-outdoor/geo-water-outdoor/AM080FXWAHR1/ (accessed on 30 July 2021).

37. S-Fuel Cell. Available online: http:/ / www.s-fuelcell.com/goods/lineUp.php (accessed on 30 July 2021).

38. Kim, J.Y.; Kwon, J.H.; Oh, J.G. Analysis of Zero Energy Building Certification Standards and Current Status. J. Kor. Inst. Ecolog. Arch. Environ. 2021, 21, 50-51.

39. Ministry of Land, Infrastructure and Transport. Energy Saving Design Standards for Buildings; Ministry of Government Legislation: Sejong, Korea, 2017. Available online: https:/ /law.go.kr/admRulSc.do? menuId=5\&subMenuId=41\&tabMenuId=183\&query=

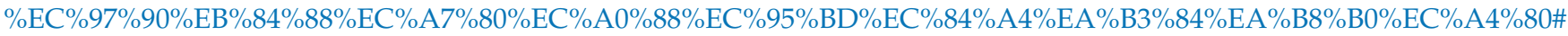
liBgcolor0 (accessed on 30 July 2021).

40. Kim, G.T.; Jang, M.K.; Song, I.H.; Kim, S.M. A Study on the Energy Self-sufficiency Rate Based on the Analysis of Building Energy Efficiency Rating System. J. Kor. Inst. Arch. Sustain. Environ. Build. Syst. 2017, 11, 331-341. 